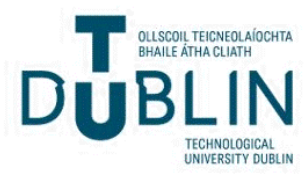

Technological University Dublin

ARROW@TU Dublin

2011-01-20

\section{Transparent Patch Antenna on a-Si Thin Film Glass Solar Module}

\author{
Maria Roo Ons \\ Technological University Dublin
}

S. Shynu

Technological University Dublin, sshynu@tudublin.ie

Max Ammann

Technological University Dublin, max.ammann@tudublin.ie

See next page for additional authors

Follow this and additional works at: https://arrow.tudublin.ie/ahfrcart

Part of the Electromagnetics and Photonics Commons, Power and Energy Commons, and the Systems and Communications Commons

\section{Recommended Citation}

Roo Ons, M. et al. (2011) Transparent Patch Antenna on a-Si Thin Film Glass Solar Module, Electronics Letters, vol. 47, no. 2, pp. 85-86, 01/2011. doi:10.1049/el.2010.7397

This Article is brought to you for free and open access by the Antenna \& High Frequency Research Centre at ARROW@TU Dublin. It has been accepted for inclusion in Articles by an authorized administrator of ARROW@TU

Dublin. For more information, please contact

arrow.admin@tudublin.ie, aisling.coyne@tudublin.ie, gerard.connolly@tudublin.ie. Funder: Science Foundation Ireland 
Authors

Maria Roo Ons, S. Shynu, Max Ammann, Sarah McCormack, and Brian Norton

This article is available at ARROW@TU Dublin: https://arrow.tudublin.ie/ahfrcart/21 


\section{Transparent patch antenna on a-Si thin-film glass solar module}

M.J. Roo-Ons, S.V. Shynu, M.J. Ammann, S.J. McCormack and B. Norton

An optically transparent microstrip patch mounted on the surface of a commercially available solar module is proposed. The patch comprises a thin sheet of clear polyester with a conductive coating. The amorphous silicon solar cells in the module are used as both a photovoltaic generator and the antenna ground plane. The proposed structure provides a peak gain of $3.96 \mathrm{dBi}$ in the $3.4-3.8 \mathrm{GHz}$ range without significantly compromising the light transmission in the module. A comparison between copper and transparent conductors is made in terms of antenna and solar performance. The proposed technique is considerably simpler than previous integration approaches.

Introduction: There is increased interest in the integration of antenna and photovoltaic technologies for terrestrial applications owing to the smaller footprint and reduced costs, which improve the economic viability of renewable energy. Various integration arrangements have been reported where the solar cell provided a ground plane function for microstrip antenna elements, but this resulted in a reduced efficiency solar cell owing to partial shading by the opaque antenna [1,2]. Materials that are both transparent and conductive such as AgHT-4, comprising a clear polyester film coated with nano-layers of metal oxides, have been developed [3].

A number of transparent antennas have been studied which show promising characteristics [4]. Recent work reports lower gain for transparent antennas compared to their copper counterparts; a transparent PIFA fabricated on a sheet of resistivity $20 \Omega$ /sq yielded approximately $10 \mathrm{~dB}$ lower gain at $2.4 \mathrm{GHz}$ [5], and a planar monopole UWB antenna on AgHT-4 was reported to have $5 \mathrm{~dB}$ lower gain owing to the inherent low conductivity of the transparent film [6].

This Letter presents a novel approach to solar antennas by mounting an optically transparent square microstrip patch made of AgHT-4 film on the surface of a glass covered solar module. This post-manufacture technique considerably simplifies the integration process by placing the radiator on the superstrate of commercially available solar modules. The transparent patch is fed using an electromagnetically-coupled microstrip feedline in a two-layer arrangement of glass-Perspex, which provides improved solar efficiency compared to previous integrated patch approaches and improved gain compared to reported transparent antennas. The AgHT-4 film used for the proposed antenna has a minimum visible light transmission (VLT) of $75 \%$ and a sheet resistivity of $4.5 \Omega / \mathrm{sq}$. The arrangement employs the solar module glass as a substrate for the microstrip feedline and an additional Perspex layer is used between the feedline and the transparent patch. The transparent antenna gain, impedance properties and radiation characteristics are evaluated and compared with a copper patch counterpart. Numerical results were obtained using CST MWS.

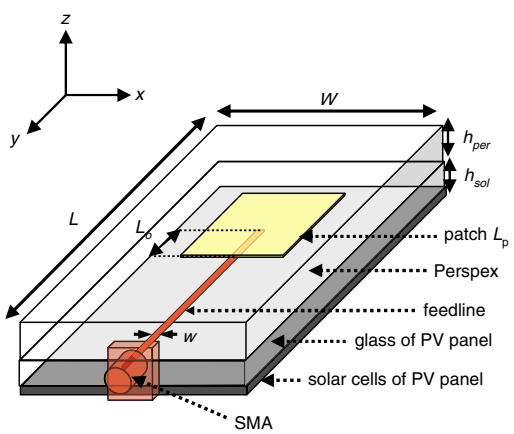

Fig. 1 Proposed antenna

Dimensions $W=55 \mathrm{~mm}, L=85 \mathrm{~mm}, L_{p}=19 \mathrm{~mm}, L_{o}=9.5 \mathrm{~mm}, w=$ $1.8 \mathrm{~mm}, h_{\text {per }}=3 \mathrm{~mm}, h_{\text {sol }}=2.3 \mathrm{~mm}$

Antenna design: The structure consists of amorphous silicon (a-Si) thinfilm solar cells, glass, Perspex and transparent AgHT-4 film layers, as shown in Fig. 1. The transparent square AgHT-4 patch of dimension $L_{p}=19 \mathrm{~mm}$ is centred on top of a clear Perspex substrate. The transparent radiator is coupled to a copper microstrip line, which is sandwiched between the Perspex and solar cell glass layer. The thin film a-Si solar cells are deposited on the rear of the glass substrate. They are $\sim 3 \mu \mathrm{m}$ thick, and comprise a layered structure of transparent conductive oxide (TCO) front electrode, $p-n$ silicon junctions, and an aluminium rear electrode. A $50 \Omega$ SMA port is connected to the copper transmission line and grounded at the edge of the aluminium rear electrode of the solar cells, thus the solar cells serve as ground plane for the microstrip antenna as well as providing the DC generation function. The transparent radiator is substituted by a copper patch of the same size for comparison purposes. The optimum feedline overlap length was found to be $L_{o}=9.5 \mathrm{~mm}$ for both copper and transparent elements.

The AgHT-4 comprises a $170 \mu \mathrm{m}$-thick clear polyester film with an $\varepsilon_{\mathrm{r}}=3.2$ and $\tan \delta=0.005$, coated with a thin layer of titanium oxide and aluminium of less than $750 \AA$. The Perspex properties are $\varepsilon_{\mathrm{r}}=$ 2.6, $\tan \delta$ is 0.015 with an overall visible light transmission of $92 \%$. The a-Si solar panel used was a Solarex plate providing a nominal output of $6.4 \mathrm{~V}$ and $54 \mathrm{~mA}(345.6 \mathrm{~mW})$. The panel glass was borosilicate with $\varepsilon_{\mathrm{r}}=6.4$ and a $\tan \delta$ of 0.02 .

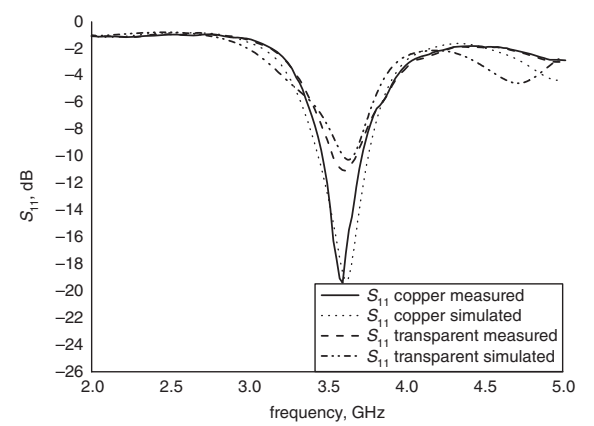

Fig. 2 Simulated and measured $S_{11}$ for copper and transparent antennas

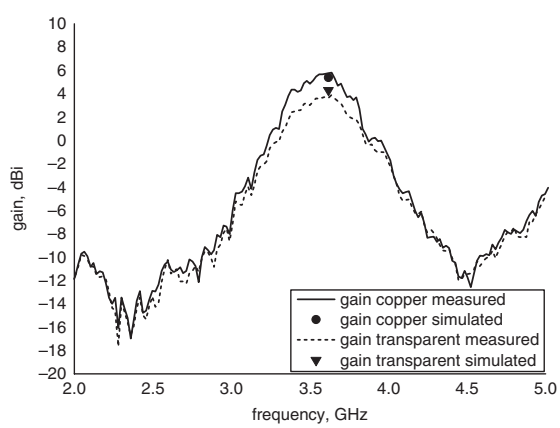

Fig. 3 Simulated and measured gain for copper and transparent antennas

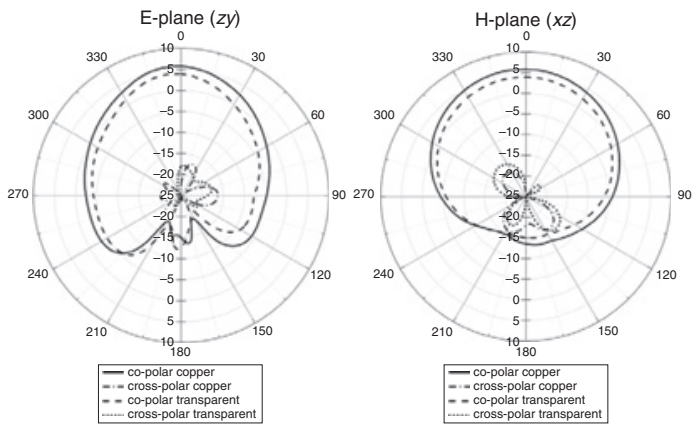

Fig. 4 Measured radiation patterns for antennas with transparent and copper patches

Results and discussion: Fig. 2 shows the measured and simulated $S_{11}$ for the proposed transparent and copper antennas, while the measured and simulated gain values are shown in Fig. 3. The measured return loss was found to be greater than $6 \mathrm{~dB}$ in the frequency range $3.390-3.850 \mathrm{GHz}$ (460 MHz) for the transparent patch and $3.372-3.845 \mathrm{GHz}(473 \mathrm{MHz})$ for the copper patch. These correspond to fractional bandwidths $\left(S_{11}<-6 \mathrm{~dB}\right)$ of 12.7 and $13.1 \%$ for the transparent and copper patches, while the $10 \mathrm{~dB}$ bandwidths are $4.3 \%(154 \mathrm{MHz})$ and $8.3 \%$ (302 MHz), respectively. The measured gain for the transparent patch was better than $2.5 \mathrm{dBi}$ across the frequency range $3.4-3.8 \mathrm{GHz}$ 
with a peak value of $3.96 \mathrm{dBi}$. The values for the copper patch were better than $3.4 \mathrm{dBi}$ across the band (with a peak of $5.81 \mathrm{dBi}$ ). Thus the difference in peak gain is $1.85 \mathrm{~dB}$. The measured $\mathrm{E}$ - and H-plane radiation patterns for the centre frequency are shown in Fig. 4. The measured cross-polar rejection is better than $-15 \mathrm{~dB}$ for both planes. The measured radiation efficiencies were 76 and $50 \%$ for the copper and transparent cases.

It is worth mentioning that the copper feedline was replaced by a transparent film feedline for the transparent antenna and a peak measured gain of $-0.8 \mathrm{dBi}$ was obtained. An early attempt to employ the Solarex panel directly as a single-layer substrate (without Perspex and using copper microstrip feed) for the transparent patch resulted in a peak gain of $-2.5 \mathrm{dBi}$; thus the combination of the Perspex and the proximity coupling are key in improving gain.

The output power of the solar antenna panel was measured while illuminated with a light intensity of $1 \mathrm{~kW} / \mathrm{m}^{2}$ to compare solar efficiencies of the transparent and copper configurations. The reduction in solar efficiency for each step of integration was found to be as follows: copper transmission line $0.56 \%$, clear Perspex $6.2 \%$, copper patch $6.5 \%$ and transparent patch $1.7 \%$. Thus the use of the transparent film improves the solar efficiency by $4.8 \%$ when compared with the use of a copper patch.

Conclusions: A novel solar antenna with an integrated transparent radiator has been modelled, fabricated and tested for use in the $3.5 \mathrm{GHz}$ band. The two-layer arrangement of an amorphous silicon solar module and Perspex was used for integration with an electromagnetically-coupled transparent patch antenna. The measured gain values are appropriate for wireless communications and sensor networks. The integration enables a reduced footprint structure.

Acknowledgment: This research was supported by the Science Foundation Ireland (05/RF/ENE 025)
(C) The Institution of Engineering and Technology 2011

27 November 2010

doi: $10.1049 / \mathrm{el} .2010 .7397$

One or more of the Figures in this Letter are available in colour online.

M.J. Roo-Ons, S.V. Shynu and M.J. Ammann (Antenna \& High Frequency Research Centre, School of Electronic and Communications Engineering, Dublin Institute of Technology, Kevin Street, Dublin 8, Ireland)

E-mail: kmariajose@yahoo.es

S.J. McCormack (Department of Civil, Structural and Enviromental Engineering, Trinity College, University of Dublin, Dublin 2, Ireland)

B. Norton (Dublin Energy Lab., Focas Institute, Dublin Institute of Technology, Camden Row, Dublin 8, Ireland)

\section{References}

1 Zawadzki, M., and Huang, J.: 'Integrated RF antenna and solar array for spacecraft application'. Proc. IEEE Phased Array Systems and Technology Conf., Dana Point, CA, USA, May 2000, pp. 239-242

2 Shynu, S.V., Roo Ons, M.J., McEvoy, P., Ammann, M.J., McCormack, S.J., and Norton, B.: 'Integration of microstrip patch antenna with polycrystalline silicon solar cell', IEEE Trans. Antennas Propag., 2009, 57, (12), pp. 3969-3972

3 Guillery, F.G.: 'Transparent, colorless, electrically conductive coating'. US Patent 4194022, 1980

4 Simons, R.N., and Lee, R.Q.: 'Feasibility study of optically transparent microstrip patch antenna'. Proc. 1997 Int. Symp. and Radio Science Meeting, Montreal, Canada, July 1997

5 Guan, N., Furuya, H., Delaume, D., and Ito, K.: 'Antennas made of transparent conductive films', PIERS online, 2008, 4, (1), pp. 116-120

6 Katsounaros, A., Hao, Y., Collings, N., and Crossland, W.A.: 'Optically transparent ultrawideband antenna', Electron. Lett., 2009, 45, (14), pp. $722-723$ 